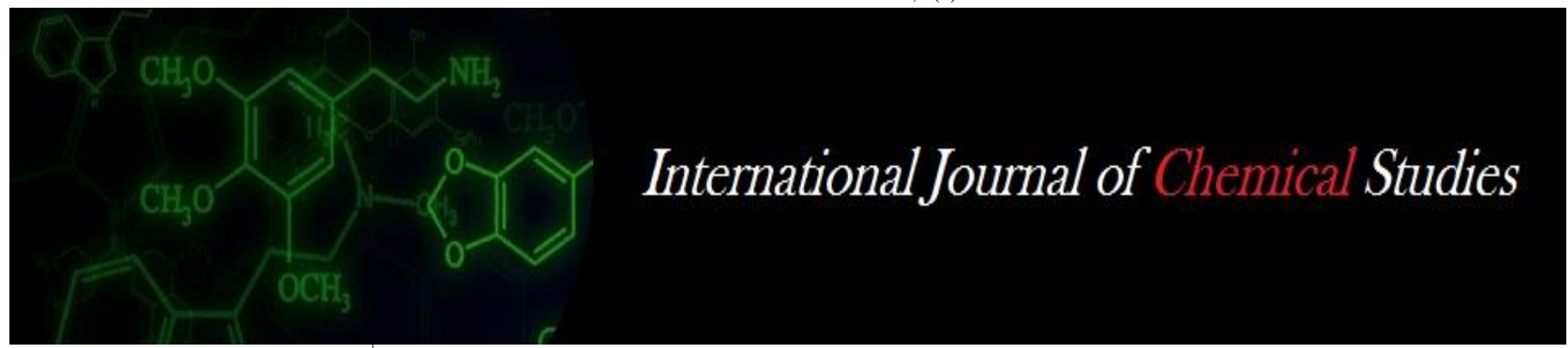

P-ISSN: 2349-8528

E-ISSN: 2321-4902

www.chemijournal.com

IJCS 2020; 8(5): 1529-1534

(C) 2020 IJCS

Received: 03-08-2020

Accepted: 08-09-2020

Abhishek Singh

Scientist-B, MSSO, P-3 Unit,

Nongpoh, Meghalaya, India

Vikram Kumar

Scientist-B, MSSO, P-3 Unit,

Nongpoh, Meghalaya, India

Sudhanshu Verma

Assistant Professor, IIAST,

Integral University, Lucknow,

Uttar Pradesh, India

Mahasankar Majumdar

Scientist-B, MSSO, P-3 Unit,

Nongpoh, Meghalaya, India

Susovan Sarka

PGDS, Krishnath College,

Berhampore, West Bengal, India

\section{Significance of vermicompost on crop and soil productivity: A review}

\author{
Abhishek Singh, Vikram Kumar, Sudhanshu Verma, Mahasankar \\ Majumdar and Susovan Sarkar
}

DOI: https://doi.org/10.22271/chemi.2020.v8.i5u.10517

\begin{abstract}
Soil performs ecological services for the survival and nourishment of life. So, maintaining and improving soil health has paramount importance for sustainability of ecosystem. Indiscriminate use of the inorganic fertilizer, pesticide has harmful effects on soil health, human health, ground water health and environment. This will caused more dangerous effect for future possibility. Present status of all food grain production is in enough quantity for population of our country so we need to improve quality of food production, quality of soil, quality of ground water and quality or healthy environment for better livelihood. These qualities are obtained by the replacing inorganic input through organic input which is more vital for present prospect and future outlook. This review paper attempts to study the use of vermicompost in crop production. It has been argued that vermicompost in crop production is productive and sustainable, but there is a need for strong support to it in the form of manifestation of subsidies, agricultural extension services and research.
\end{abstract}

Keywords: Soil, vermicompost, soil health, human health

\section{Introduction}

Agro-industrial sector contributes huge resources of plants nutrients in the form of wastes like animal manure, food waste, sewage sludge and industrial organic wastes which is either terrified away or burnt causing environmental pollution. Conventional composting of press mud takes about half a year and has less nutritive value. Decomposition of these waste by using different species of earthworms Eisenia foetida, Lampito mauritii, Eudrilus eugeniae and Perionyx excavates can be converted into an eco-friendly organic manure soil amendment and these vermicompost shows ample plant nutrient content and enzymatic microbial activities facilitating the easy uptake by the plants (Parthasarthi and Ranganathan, 2002) [40]. Vermicomposting is an economically and environmentally friendly process of decomposition of organic waste. Vermicompost is a very nutritive organic manure having ample amount of humus, nitrogen $(\mathrm{N})$ 2-3\% phosphorous (P) 1.55-2.25\%, potassium (K) 1.85-2.25\%, micro nutrients, and soil microbes like 'nitrogen fixing bacteria' and mycorrhizal fungi. Vermicompost has been scientifically proved as miracle plant growth enhancer (Chaoui et al., 2003) ${ }^{[18]}$. Ansari and Ismail (2012) ${ }^{[3]}$ reported that worm's vermicompost contains $7.37 \%$ nitrogen and $19.58 \%$ phosphorous as $\mathrm{P} 2 \mathrm{O} 5$. Microbial population of N2-fixing bacteria and Actinomycetes increases after application of vermicompost. The intensified microbial activities improve the availability of soil phosphorous, nitrogen and micro nutrients (Chanda et al., 2011) ${ }^{[17]}$. Vermicompost stimulates to influence the microbial activity of soil, improve water holding capacity of soil, increases the availability of oxygen, increases soil porosity and infiltration of water, maintain soil temperature, improves nutrient content and increases growth, yield and quality of the plant (Arora et al., 2011) ${ }^{[9]}$.

Extensive usage of inorganic fertilizers and pesticides in agriculture has lead to environmental problem like pesticide residue in food, bioaccumulation and biomagnifications of pesticides in food web and deterioration of soil health. Owing to wide spectrum of problems with the use of chemical fertilizer, organic farming is becoming popular among the farming community. Vermicompost play a significant role in organic-based farming system such as organic farming or sustainable farming and in numerous ways account for crop nourishment, soil productivity enhancement and providing sustainability to farming system (Varghese and Prabha, 2014) ${ }^{[54]}$.
Corresponding

Scientist-B, MSSO, P-3 Unit

Nongpoh, Meghalaya, India 
Here we have emphasized different positive aspect of vermicompost one by one for easily understanding.

\section{Effects of Vermicompost on Plant Growth and its final product}

Vermicompost plays a major role in improving growth and yield of different field crops, vegetables, flower and fruit crops. The application of vermicompost gave higher germination $(93 \%)$ of mung bean compared with bio digested slurry $(84 \%)$. Further, the growth and yield of mung bean was also significantly higher with vermicompost application (Karmegam et al., 1999) ${ }^{[33]}$. Likewise, in another pot experiment, the fresh and dry matter yields of cowpea were higher when soil was amended with vermicompost than with biodigested slurry (Karmegam and Daniel, 2000) ${ }^{[33]}$. The application of vermicompost along with fertilizer $\mathrm{N}$ gave higher dry matter $\left(16.2 \mathrm{~g} \mathrm{plant}^{-1}\right)$ and grain yield $\left(3.6 \mathrm{t} \mathrm{ha}^{-1}\right)$ of wheat and higher dry matter yield $\left(0.66 \mathrm{~g} \mathrm{plant}^{-1}\right)$ of the following coriander crop in sequential cropping system(Verma et al., 2017) ${ }^{[58]}$. Similarly, a positive response was obtained with the application of vermicompost to other field crops such as sorghum (Patil and Sheelavantar, 2000) ${ }^{[41]}$ and sunflower (Devi and Agarwal, 1998) ${ }^{[20]}$. Application of vermicompost at $5 \mathrm{t} \mathrm{ha}^{-1}$ significantly increased yield of tomato $\left(5.8 \mathrm{t} \mathrm{ha}^{-1}\right)$ compared to application of farmyard manure (3.5 $\left.\mathrm{t} \mathrm{ha}^{-1}\right)$ (Verma et al., 2017) ${ }^{[58]}$. Similarly, greenhouse studies have indicated that vermicompost enhances transplant growth rate of vegetables. Amendment of vermicompost to vegetables had the highest amount of red marketable fruit at harvest. In addition, there were no symptoms of early blight lesions on the fruit at harvest. The yield of pea was also higher with the application of vermicompost $\left(10 \mathrm{t} \mathrm{ha}^{-1}\right)$ along with recommended $\mathrm{N}, \mathrm{P}$ and $\mathrm{K}$ than with these fertilizers alone (Reddy et al., 1998) ${ }^{[45]}$. Vadiraj et al., (1998) reported that application of vermicompost produced herbage yields of coriander cultivars that were comparable to those obtained with chemical fertilizers. Nethra et al, (1999) ${ }^{[39]}$ reported that the fresh weight of flowers of Chrysanthemum chinensis increased with the application of different levels of vermicompost. Also, the number of flowers per plant $(26)$, flower diameter $(6 \mathrm{~cm})$ and yield $\left(0.5 \mathrm{t} \mathrm{ha}^{-1}\right)$ were maximum with the application of $10 \mathrm{t} \mathrm{ha}^{-1}$ of vermicompost along with $50 \%$ of recommended dose of NPK fertilizer. However, the vase life of flowers (11 days) was high with the combined application of vermicompost at $15 \mathrm{t} \mathrm{ha}^{-1}$ and $50 \%$ of recommended dose of NPK fertilizer. An experiment conducted by Alam et al., 2007 ${ }^{[2]}$, to study the effect of vermicompost and NPKS fertilizers on growth and yield of potato (cv. Cardinal) in Bangladesh, suggested that $100 \%$ inorganic fertilizers with $5-10 \mathrm{t} \mathrm{ha}^{-1}$ of vermicompost is suitable for higher production of potato and economically profitable.

In the present study vermicompost produced significant improvements in the growth and yield of sweet corn, as also reported by Atiyeh et al., (2000) ${ }^{[11]}$, Arancon et al., (2004) ${ }^{[7]}$ and Singh et al., (2008) [50], Verma et al., (2017) [58]. Replacement of $25 \%$ of the nutrients provided to the plants by vermicompost produced significant greater increases in plant height and marketable crop yield than those produced by $100 \%$ inorganic fertilization. Nevertheless the magnitude of such effects was relatively small and not general, with a large degree of variability between the different hybrids assayed. Furthermore, there was little or no difference from the effects produced by manure on plant height and crop yield. Interestingly, increases in sweet corn growth and marketable yield were produced by both the normal and the high doses of vermicompost and manure, indicating that these effects were independent of the amount of N, P and K provided. Foliar analysis revealed that the differences in macronutrient content between the plants cultivated with the three types of fertilizers were minor. However, plants cultivated with vermicompost showed a slightly higher foliar P content. The same amounts of nutrients (NPK) were supplied with each dose of the three fertilizers and therefore the higher foliar phosphor us content in plants amended with vermicompost presumably corresponds to greater availability of this nutrient in the soil. Vermicompost significantly stimulates the growth of a wide range of plant species including several horticultural crops such as tomato (Hashemimajd et al., 2004; Gutiérrez-Miceli et al., 2007, Verma et al., 2018) ${ }^{[26,25,56-57]}$, pepper (Arancon et al., 2005) ${ }^{[6]}$, garlic (Argüello et al., 2006) ${ }^{[8]}$, aubergine (Gajalakshmi and Abbasi, 2004) ${ }^{[23]}$, strawberry (Arancon et al., 2004) ${ }^{[7]}$, sweet corn and green gram (Karmegam et al., $1999)^{[33]}$. Vermicompost has also been found to have positive effects on some aromatic and medicinal plants (Anwar et al., 2005; Prabha et al., 2007) ${ }^{[4,43]}$, cereals such as sorghum and rice (Bhattacharjee et al., 2001; Reddy and Ohkura, 2004; Sunil et al., 2005) ${ }^{[13,45,52]}$, fruit crops such as banana and papaya (Cabanas-Echevarria, et al., 2005) ${ }^{[14]}$, and ornamentals such as geranium (Chand et al., 2007) ${ }^{[16],}$ marigolds (Atiyeh et al., 2002) ${ }^{[10]}$, petunia (Arancon et al., 2008) ${ }^{[5]}$, chrysanthemum (Hidalgo and Harkess, 2002a) [27] and poinsettia (Hidalgo and Harkess, 2002b) ${ }^{[28]}$. Positive effects of vermicompost have also been observed in forestry species such as acacia, eucalyptus and pine tree (Donald and Visser, 1989, Lazcano et al., 2010, Verma et al., 2018) ${ }^{[21,35,}$ 56-57]. Vermicompost has been found to have beneficial effects when used as a total or partial substitute for mineral fertilizer in peat-based artificial greenhouse potting media and as soil amendments in field studies. Likewise, some studies show that vermicomposting leachates or vermicompost waterextracts, used as substrate amendments or foliar sprays, also promote the growth of tomato plants (Tejada et al., 2008, Verma et al., 2018, Verma, 2016) [53, 56-57, 55], sorghum (Gutiérrez-Miceli et al., 2008) ${ }^{[24]}$, and strawberries (Singh et al., 2010) ${ }^{[49]}$. Positive effects of vermicompost include stimulated seed germination in several plant species such as green gram (Karmegam et al., 1999) [33], tomato plants (Zaller, 2007) ${ }^{[60]}$, petunia (Arancon et al., 2008) ${ }^{[5]}$ and pine trees (Lazcano et al., 2010) ${ }^{[35]}$. Vermicompost also has a positive effect on vegetative growth, stimulating shoot and root development (Edwards et al., 2004) ${ }^{[7]}$. The effects include alterations in seedling morphology such as increased leaf area and root branching (Lazcano et al., 2009) ${ }^{\text {[34]. }}$ Vermicompost has also been shown to stimulate plant flowering, increasing the number and biomass of the flowers produced (Atiyeh et al., 2002; Arancon et al., 2008) ${ }^{[10,5]}$, as well as increasing fruit yield (Atiyeh, et al., 2000; Arancon et al., 2004; Singh et al., $2008^{[50]}$,Verma et al., 2018, Verma, 2016) ${ }^{[11,7,56-57,55]}$. In addition to increasing plant growth and productivity, vermicompost may also increase the nutritional quality of some vegetable crops such as tomatoes (GutiérrezMiceli et al., 2007) ${ }^{[25]}$, Chinese cabbage (Wang et al., 2010) [59], spinach (Peyvast et al., 2008) ${ }^{[42]}$, strawberries (Singh et al., 2008) [50], lettuce (Coria- Cayupán et al., 2009) [19], and sweet corn (Lazcano et al., 2011, Verma et al., 2018, Verma, 2016) $[56-57,55]$. Nevertheless, despite the large body of scientific evidence showing the positive effects of vermicompost on plant growth and yield, there is also strong evidence that these effects are not general or constant, and 
that there is great variability in the magnitude of the effects reported in different studies. In fact, some studies report that vermicompost may decrease growth and even cause plant death (Roberts et al., 2007) ${ }^{[46]}$. The variability in the effects of vermicompost may depend on the cultivation system into which it is incorporated, as well as on the physical, chemical and biological characteristics of vermicompost, which vary widely depending on the original feedstock, the earthworm species used, the production process, and the age of vermicompost (Rodda et al., 2006; Roberts et al., 2007) ${ }^{[47,46]}$. There is also a large variation in the effects of vermicompost depending on the plant species or even the variety considered. This was observed in tomato plants where the replacement of a fertilized commercial potting media with vermicompost had different effects on germination, seedling elongation, biomass allocation, fruit morphology and chemical properties of three tomato varieties (Zaller, 2007, Verma et al., 2018, Verma, 2016, [60, 56-57, 55]. Similar variation was observed in an experiment studying the effects of vermicompost and vermicompost extracts on the germination and early growth of six different progenies of maritime pine Lazcano et al. (2010) [35]. Same study revealed that the speed of maturation increased with vermicompost, relative to the control, in three out of the six pine progenies, decreased in two of the progenies and was unaffected in the other. It may be expected that different hybrids or plant genotypes will respond differently to vermicompost, considering that plant genotype determines important differences in nutrient uptake capacity, nutrient use efficiency and resource allocation within the plant. Different genotypes may therefore enhance root growth or modify root exudation patterns in order to increase nutrient uptake (Kabir et al., 1998; Cavani and Mimmo, 2007) ${ }^{[30,15],}$ and all of these strategies will determine the establishment of different interactions with the microbial communities at the rhizosphere level. In fact, after the application of vermicompost to sweet corn crops, the different genotypes showed important differences in their rhizosphere microbial community (Aira et al., 2010) ${ }^{[1]}$. In light of this evidence, it is clear that vermicompost constitutes a promising alternative to inorganic fertilizers in promoting plant growth. However, further research into the exact mechanisms and circumstances that stimulate plant growth by this organic substrate is necessary in order to maintain consumer confidence in this type of fertilizer.

\section{Effect of Vermicompost on Nutrient Uptake}

The earthworms are the agents of turning, fragmentation and aeration. It also increase $\mathrm{N}_{2}$ fixation by both nodular and free living $\mathrm{N}_{2}$ fixing bacteria result enhance plant growth. Vermicompost has been proved as cheapest source of nitrogen and other essential elements for better nodulation and yield particularly in legumes. Such plants can meet their N needs through both biological nitrogen fixation (symbiosis) and native nitrogen in the soil (Ranganathan and Parthasarathi, 2002, Babu et al., 2017, Verma, 2016) ${ }^{[40,12,55]}$. Sreenivas et al., (2000) ${ }^{[51]}$ studied the integrated effect of application of fertilizer and vermicompost on soil available nitrogen and uptake of ridge gourd. Soil available $\mathrm{N}$ increased significantly with increasing levels of vermicompost and highest $\mathrm{N}$ uptake was obtained at $50 \%$ of the recommended fertilizer rate plus $10 \mathrm{t} \mathrm{ha}^{-1}$ vermicompost. Similarly, the uptake of nitrogen, phosphorus, potassium and magnesium by rice plant was highest when fertilizer was applied in combination with vermicompost (Verma et al., 2018, Babu et al., 2017, Verma, 2016, Jadhav et al., 1997) ${ }^{[56-57,55,12]}$. Similarly, Sailaja kumari and Ushakumari (2002) ${ }^{[36]}$ studied the effect of enriched vermicompost with rock phosphate on the yield and uptake of nutrients by cowpea and revealed that enriched vermicompost showed its superiority over other treatments for uptake of major nutrients like $\mathrm{N}, \mathrm{P}, \mathrm{K}, \mathrm{S}, \mathrm{Ca}$, and $\mathrm{Mg}$.

\section{Effects of Vermicompost on Soil Biochemical and Microbiological Properties}

Regarding the nutrient content of the soil at harvest there were no differences in $\mathrm{N}-\mathrm{NH}_{4}+, \mathrm{N}-\mathrm{NO}_{3}-$ or $\mathrm{K}_{2} \mathrm{O}_{5}$ between the fertilizing treatments and doses applied. However, the $\mathrm{PO}_{4}-$ content of the soil was significantly higher in the plots to which vermicompost was added than in the plots that received only inorganic fertilizers or manure. However, this only took place at the high doses applied, whereas there were no differences between the treatments at the normal doseGlucosidase, protease and alkaline phosphomonoesterase enzyme activity rates were significantly higher in the soil plots amended with vermicompost and manure than in those treated with inorganic fertilizer. Fertilization with vermicompost and manure also favored growth of microorganisms in the soil. Bacterial growth increased significantly after application of the high doses of vermicompost and manure, although fungal growth was not affected. Organic amendments promoted microbial growth, which resulted in a higher soil microbial biomass, although only in the plots treated with manure. The increase in soil microbial biomass was due exclusively to an increase in Gram-negative bacteria, as shown by the increased concentration of the PLFAs (phospholipids fatty acid) biomarkers for this microbial group. Replacement of $25 \%$ of the nutrients provided to the corn plants by vermicompost maintains plant productivity at the same levels than $100 \%$ inorganic fertilization. In addition, vermicompost produces significant changes in soil biochemical and microbial properties promoting bacterial growth and increasing enzyme activity. In spite of the fact that the same amounts of N, P and $\mathrm{K}$ were provided with the three types of fertilizers at each dose, vermicompost amended plots exhibited higher phosphatase and phosphate levels, and the $\mathrm{P}$ content of the plants was higher than in soils with inorganic fertilization. The results presented here confirm that there is a large variation in vermicompost effects depending on the plant genotype. Therefore, within a given crop certain genotypes or varieties may be more suitable for organic or combined inorganic-organic cropping systems, than others.

\section{Effect of Vermicompost on Soil Physical, Chemical and Biological properties}

Studies on vermicompost indicate that it increases macro pore space ranging from 50 to $500 \mu \mathrm{m}$, resulting in improved airwater relationship in the soil which favorably affects plant growth (Verma et al., 2018, Verma, 2016, Marinari et al., 2000) $[56-57,55]$. The application of organic matter including vermicompost favorably affects soil $\mathrm{pH}$, microbial population and soil enzyme activities (Maheswarappa et al., 1999) ${ }^{[37]}$. It also reduces the proportion of water-soluble chemical species, which cause possible environmental contamination (Mitchell and Edwards, 1997) ${ }^{[38]}$. A field experiment was conducted by Kannan et al., (2005) ${ }^{[31]}$, with tomato to study the influence of different organic N sources viz, FYM, Vermicompost and compost with bioferilizers on the soil physical properties, nutrient availability and biological properties reported application of vermicompost $(75 \% \mathrm{~N})$ with azospirillum was found superior in influencing the soil physical, chemical and 
biological environment such as bulk density, soil porocity, water holding capacity, organic carbon, available nitrogen, beneficial bacterial and fungal population over the other treatments.

\section{Advantages of Vermicompost}

Many researchers conducted various experiments on vermicompost to examine its chemical and biological aspect. A few scientist coated advantages of vermicompost which is describe below.

- It is rich in all essential plant nutrients and contains valuable vitamins, enzymes and hormones like auxins, gibberellins etc.

- Provides excellent effect on overall plant growth, encourages the growth of new shoots / leaves and improves the quality and shelf life of the produce.

- It is free flowing, easy to apply, handle and store and does not have bad odour.

- It improves soil structure, texture, aeration, and water holding capacity and prevents soil erosion.

- It is rich in beneficial micro flora such as a fixers, Psolubilizers, cellulose decomposing micro-flora etc in addition to improve soil environment.

- It contains earthworm cocoons and increases the population and activity of earthworm in the soil.

- It prevents nutrient losses and increases the use efficiency of chemical fertilizers and enhances the decomposition of organic matter in soil.

- It is free from pathogens, toxic elements, weed seeds etc. and minimizes the incidence of pest and diseases.

\section{Conclusions}

Vermicompost can be described as a complex mixture of earthworm faeces, humified organic matter and microorganisms, which when added to the soil or plant growing media, increases germination, growth, flowering, fruit production and accelerates the development of a wide range of plant species. The enhanced plant growth may be attributed to various direct and indirect mechanisms, including biologically mediated mechanisms such as the supply of plant-growth regulating substances, and improvements in soil biological functions. Use of this type of organic fertilizer therefore has great potential; however some recent studies raise serious doubts about the general applicability of these results and propose a more complex model of action for these types of effects. Stimulation of plant growth may depend mainly on the biological characteristics of vermicompost, the plant species used, and the cultivation conditions. Extensive research on inorganic fertilization and plant breeding, carried out within the framework of conventional agriculture, has allowed agricultural producers to fine-tune nutrient inputs and plant needs in order to maximize yields. However, such detailed knowledge has not yet been attained as regards the interactions between plants and organic fertilizers in sustainable agriculture. Given the complex and variable composition of vermicompost in comparison with inorganic fertilizers and the myriad of effects that it can have on soil functioning, a clear and objective concept of vermicompost is required, and the complex interactions between vermicompost-soil-plant must be unraveled in order to maintain consumer confidence in this type of organic fertilizer.

\section{References}

1. Aira M, Gómez-Brandón M, Lazcano C, Bååth E, Domínguez J. Plant genotype strongly modifies the structure and growth of maize rhizosphere microbial communities. Soil Biology and Bioche. Mistry. 2010; 42(12):2276-2281.

2. Alam MN, Jahan MS, Ali MK, Ashraf MA, Islam MK. Effect of vermicompost and chemical fertilizers on growth, yield and yield components of potato in barind soils of Bangladesh. J of Applied Sciences Res. 2007; 3(12):1879-1888.

3. Ansari AA, Ismail SA. Relamation of sodic soils through vermitechnology. Pakistan J Agric Res. 2008; 21:92-97

4. Anwar M, Patra DD, Chand S, Kumar A, Naqvi AA, Khanuja SPS. Effect of organic manures and inorganic fertilizer on growth, herb and oil yield, nutrient accumulation, and oil quality of French basil. Communications in Soil Science and Plant Analysis. 2005; 36(1-14):1737-1746.

5. Arancon NQ, Edwards CA, Babenko A, Cannon J, Galvis $\mathrm{P}$, Metzger JD. Influences of vermicomposts, produced by earthworms and microorganisms from cattle manure, food waste and paper waste, on the germination, growth and flowering of petunias in the greenhouse, Applied Soil Ecology. 2008; 39:91-99.

6. Arancon NQ, Edwards CA, Bierman P, Metzger JD, Lucht C. Effects of vermicomposts produced from cattle manure, food waste and paper waste on the growth and yield of peppers in the field. Pedobiologia. 2005; 49:297306.

7. Arancon NQ, Edwards CA, Bierman P, Welch C, Metzger JD. Influences of vermicomposts on field strawberries: 1. effects on growth and yields. Bioresource Technology. 2004; 93:145-153.

8. Argüello JA, Ledesma A, Núñez SB, Rodríguez $\mathrm{CH}$, Díaz Goldfarb MDC. Vermicompost effects on bulbing dynamics nonstructural carbohydrate content, yield, and quality of 'Rosado Paraguayo' garlic bulbs. Hortscience. 2006; 41(3):589-592.

9. Arora VK, Singh CB, Sidhu AS, Thind SS. Irrigation, tillage and mulching effects on Soybean yield and water productivity in relation to soil texture. Agric Water Manag. 2011; 98(4):563-568.

10. Atiyeh RM, Arancon N, Edwards CA, Metzger JD. The influence of earthworm-processed pig manure on the growth and productivity of marigolds. Bioresource Technology. 2002; 81:103-108.

11. Atiyeh RM, Dominguez J, Sobler S, Edwards CA. Changes in biochemical properties of cow manure during processing by earthworms (Eisenia andrei) and the effects on seedling growth. Pedobiologia. 2000; 44:709-724.

12. Babu A, Verma S, Yadav SSS, Singh YV. Impact of Nutrient Management Technologies, Soil Biomass and Enzymatic Activities in Transplanted Rice (Oryza sativa L.) Under Irrigated Domains of Eastern Plain Zone in India. International Journal of Current Microbiology and Applied Sciences. 2017; 6(11):4219-4227.

13. Bhattacharjee G, Chaudhuri PS, Datta M. Response of paddy (Var. TRC-87-251) crop on amendment of the field with different levels of vermicompost. Asian Journal of Microbiology, Biotechnology and Environmental Sciences. 2001; 3(3):191-196.

14. Cabanas-Echevarría M, Torres-García A, DíazRodríguez B, Ardisana EFH, Creme-Ramos Y. Influence of three bioproducts of organic origin on the production of two banana clones (Musa spp AAB.) obtained by tissue cultures. Alimentaria. 2005; 369:111-116. 
15. Cavani N, Mimmo T. Rhizodeposition of Zea mays L. as affected by heterosis. Archives of Agronomy and Soil Science. 2007; 53:593-604.

16. Chand S, Pande P, Prasad A, Anwar M, Patra DD. Influence of integrated supply of vermicompost and zincenriched compost with two graded levels of iron and zinc on the productivity of geranium. Communications in Soil Science and Plant Analysis. 2007; 38:2581-2599.

17. Chanda GC, Bhunia G, Chakraborty SK. The effect of vermicompost and other fertilizers on cultivation of Tomato plants. J Hortic For. 2011; 3:42-45.

18. Chaoui HI, Zibilske LM, Ohnot. Effects of earthworms cast and compost on soil microbial activity and plant nutrient availability. Soil Biol Biochem. 2003; 35:295302.

19. Coria-Cayupán YS, De Pinto MIS, Nazareno MA. Variations in bioactive substance contents and crop yields of lettuce (Lactuca sativa L.) cultivated in soils with different fertilization treatments. Journal of Agricultural and Food Chemistry. 2009; 57(21):10122-10129.

20. Devi D, Agarwal SK. Performance of sunflower hybrids as influenced by organic manure and fertilizer. J. of Oilseeds Research. 1998; 15:272-279.

21. Donald DGM, Visser LB. Vermicompost as a possible growth medium for the production of commercial forest nursery stock. Appl. Plant Sci. 1989; 3:110-113.

22. Edwards CA, Domínguez J, Arancon NQ. The influence of vermicomposts onplant growth and pest incidence. In: S.H Shakir and W.Z.A. Mikhaïl, (Eds). Soil Zoology for Sustainable Development in the 21st century, 2004, 397420, Cairo.

23. Gajalakshmi S, Abbasi SA. Neem leaves as a source of fertilizer-cum-pesticide vermicompost. Bioresource Technology. 2004; 92:291-296.

24. Gutiérrez-Miceli FA, García-Romero RC, RincónRosales R, Abud-Archila M, Oliva- Llaven MA, GuillenCruz MJ et al. Formulation of a liquid fertilizer for sorghum (Sorghum bicolor (L.) Moench) using vermicompost leachate. Bioresource Technology, 2008.

25. Gutiérrez-Miceli FA, Santiago-Borraz J, Montes Molina JA, Nafate CC, Abdud- Archila M, Oliva Llaven MA et al. Vermicompost as a soil supplement to improve growth, yield and fruit quality of tomato (Lycopersicum esculentum). Bioresource Technology. 2007; 98:27812786.

26. Hashemimajd K, Kalbasi M, Golchin A, Shariatmadari H. Comparison of vermicompost and composts as potting media for growth of tomatoes. Journal of Plant Nutrition. 2004; 6:1107-1123.

27. Hidalgo PR, Harkess RL. Earthworm casting as a substrate amendment for Chrysanthemum Production. Hortscience. 2002a; 37(7):1035-1039.

28. Hidalgo PR, Harkess RL. Earthworm casting as a substrate for Poinsettia production. Hortscience. 2002b; 37(2):304-308.

29. Jadhav AD, Talashilkar SC, Pawar AG. Influence of the conjunctive use of FYM, vermicompost and urea on growth and nutrient uptake in rice. J. of Maharashtra Agricultural Universities. 1997; 22:249-250.

30. Kabir Z, O'Halloran IP, Fyles JW, Hamel C. Dynamics of the mycorrhizal symbiosis of corn (Zea mays L.): effects of host physiology, tillage practice and fertilization on spatial distribution of extra-radical mycorrhizal hyphae in the field. Agriculture, Ecosystems and Environment. 1998; 68:151-163.
31. Kannan P, Saravanan A, Krishnakumar S, Natarajan SK. Biological Properties of Soil as Influenced by Different Organic Manures. Res. J of Agriculture and Biological Sciences. 2005; 1:181-183.

32. Karimi H, Mokhtari M, Salehi F, Sojoudi S, Ebrahimi A. Changes in microbial pathogen dynamics during vermicomposting mixture of cow manure-organic solid waste and cow manuresewage sludge. Int $\mathbf{J}$ Recycl Org Waste Agric. 2017; 6:57-61.

33. Karmegam N, Alagumalai K, Daniel T. Effect of vermicompost on the growth and yield of green gram (Phaseolus aureus Roxb.). Tropical Agriculture. 1999; 76:143-146.

34. Lazcano C, Arnold J, Tato A, Zaller JG, Domínguez J. Compost and vermicompost as nursery pot components: Effects on tomato plant growth and morphology. Spanish Journal of Agricultural Research. 2009; 7:944-951.

35. Lazcano C, Sampedro L, Zas R, Domínguez J. Vermicompost enhances germination of the maritime pine (Pinus pinaster Ait.). New Forest. 2010; 39:387400.

36. Sailaja Kumari MS, Ushakumari K. Effect of vermicompost enriched with rock phosphate on the yield and uptake of nutrients in cowpea (Vigna unguiculata). J of Tropical Agriculture. 2002; 40:27-30.

37. Maheswarappa HP, Nanjappa HV, Hegde MR. Influence of organic manures on yield of arrowroot, soil physicochemical and biological properties when grown as intercrop in coconut garden. Annals of Agricultural Research. 1999; 20:318-323.

38. Mitchell A, Edwards CA. The production of vermicompost using Eisenia fetida from cattle manure. Soil Biology and Biochemistry. 1997; 29:3-4.

39. Nethra NN, Jayaprasad KV, Kale RD. China aster [Callistephus chinensis (L)] cultivation using vermicompost as organic amendment. Crop Research, Hisar. 1999; 17:209-215.

40. Parthasarthi K, Ranganathan LS. Supplementation of presumed vermicast with NPK enhances growth and yield in Leguminous crops (Vigna mungo and Arachis hypogaea). J Carr Sci. 2002; 2:35-41.

41. Patil SL, Sheelavantar MN. Effect of moisture conservation practices, organic sources and nitrogen levels on yield, water use and root development of rabi sorghum [Sorghum bicolor (L.)] in the vertisols of semiarid tropics. Annals of Agricultural Research. 2000; 21(21):32-36.

42. Peyvast G, Olfati JA, Madeni S, Forghani A. Effect of vermicompost on the growth and yield of spinach (Spinacia oleracea L.). Journal of Food Agriculture and Environment. 2008; 6:110-113.

43. Prabha ML, Jayraay IA, Jayraay R, Rao DS. Effect of vermicompost on growth parameters of selected vegetable and medicinal plants. Asian Journal of microbiology, Biotechnology and Environmental Sciences. 2007; 9(2):321-326.

44. Ranganathan LS, Parthasarathi K. Enhanced phosphatase activity in earthworm casts is more of microbial origin. Current Science. 2000; 79:1158-1159.

45. Reddy MV, Ohkura K. Vermicomposting of rice-straw and its effects on sorghum growth. Tropical Ecology. 2004; 45(2):327-331.

46. Roberts P, Jones DL, Edwards-Jones G. Yield and vitamin $\mathrm{C}$ content of tomatoes grown in vermicomposted 
wastes. Journal of the Science of Food and Agriculture. 2007; 87:1957-1963.

47. Rodda MRC, Canellas LP, Façanha AR, Zandonadi DB, Guerra JGM, De Almeida DL et al. Improving lettuce seedling root growth and ATP hydrolysis with humates from Vermicompost. II- Effect of Vermicompost source. Revista Brasileira de Ciencia do Solo. 2006; 30:657-664.

48. Singh BK, Pathak KA, Verma AK, Verma VK, Deka BC. Effects of vermicompost, fertilizer and mulch plant growth, nodulation and pod yield of French bean (Phaseolus vulgaris). Veg Crop Bulletin. 2011; 74:153165.

49. Singh R, Gupta RK, Patil RT, Sharma RR, Asrey R, Kumar A, Jangra KK. Sequential foliar application of vermicompost leachates improves marketable fruit yield and quality of strawberry (Fragaria $x$ ananassa Duch.). Scientia Horticulturae. 2010; 124:34-39.

50. Singh R, Sharma RR, Kumar S, Gupta RK, Patil RT. Vermicompost substitution influences growth, physiological disorders, fruit yield and quality of strawberry (Fragaria $x$ ananassa Duch.). Bioresource Technology. 2008; 99:8507-8511.

51. Sreenivas C, Muralidhar S, Rao MS. Vermicompost, a viable component of IPNSS in nitrogen nutrition of ridge gourd. Annals of Agricultural Research. 2000; 21(1):108113.

52. Sunil K, Rawat CR, Shiva D, Suchit KR. Dry matter accumulation, nutrient uptake and changes in soil fertility status as influenced by different organic and inorganic sources of nutrients to forage sorghum (Sorghum bicolor). Indian Journal of Agricultural Science. 2005; 75(6):340-342.

53. Tejada M, Gonzalez JL, Hernandez MT, Garcia C. Agricultural use of leachates obtained from two different vermicomposting processes, Bioresource Technology. 2008; 99:6228-6232.

54. Varghese SM, Prabha ML. Biochemical characterization of vermiwash and its effect on growth of Capsicum frutescens. MalayaJ Biosci. 2014; 1(2):86-91

55. Verma S. Bio-efficacy of organic formulations along with fertilizers on growth, yield and quality of pigeonpea [Cajanus cajan (L.) Millsp] (Doctoral dissertation, Institute of Agricultural Sciences, Banaras Hindu University), 2016.

56. Verma S, Babu A, Patel A, Singh SK, Pradhan SS, Verma SK et al. Significance of vermiwash on crop production: A review. Journal of Pharmacognosy and Phytochemistry. 2018; 7(2):297-301.

57. Verma S, Singh A, Pradhan SS, Singh JP, Verma SK. Effects of organic formulations and synthetic fertilizer on the performance of pigeonpea in eastern region of Uttar Pradesh. Bangladesh Journal of Botany. 2018; 47(3):467471.

58. Verma S, Singh A, Pradhan SS, Singh RK, Singh JP. Bio-efficacy of organic formulations on crop productionA review. International Journal of Current Microbiology and Applied Sciences. 2017; 6(5):648-665.

59. Wang D, Shi Q, Wang X, Wei M, Hu J, Liu J et al. Influence of cow manure vermicompost on the growth, metabolite contents, and antioxidant activities of Chinese cabbage (Brassica campestris ssp. chinensis). Biology and Fertility of Soils. 2010; 46:689-696.

60. Zaller JG. Vermicompost as a substitute for peat in potting media: Effects on germination, biomass allocation, yields and fruit quality of three tomato varieties. Scientia Horticulturae. 2007; 112:191-199. 